EWA MANIKOWSKA

https://orcid.org/0000-0001-6633-823X

Instytut Sztuki Polskiej Akademii Nauk

\title{
MUZEA PRZEMYSŁOWE W KRAKOWIE I WE LWOWIE. GENEZA I PIERWSZY OKRES DZIAŁALNOŚCI (1868-1914) ${ }^{1}$
}

Zarys treści: Artykuł przedstawia wczesną działalność galicyjskich muzeów przemysłowych w Krakowie i we Lwowie. Jest ona analizowana jako przykład twórczej adaptacji w prowincjonalnych ośrodkach imperiów modeli i wzorców wypracowanych w ówczesnych europejskich stolicach. Szczególną uwagę zwracono na obywatelski charakter obu instytucji oraz ich rolę w kształtowaniu tożsamości miejskich, regionalnych i narodowych. Choć oba analizowane muzea wzorowane były na przykładach zagranicznych, a zwłaszcza South Kensington Museum i Imperial-Royal Museum of Art and Industry, odwoływały się do ich statutów i programów, prowadziły z instytucjami w Wiedniu i innych ośrodkach Cesarstwa ożywioną wymianę naukowa, należały do sieci muzeów przemysłowych w Cesarstwie, to każde z nich miało swój odrębny rys lokalny, kształtowany dzięki zaangażowaniu miejskich stowarzyszeń, instytucji i obywateli.

The content outline: The article discusses the early stages in the activity of industrial museums founded in Kraków and Lviv. The issue is analyzed as an example of creative adaptation of models and blueprints developed in the erstwhile European capitals to the reality of provincial imperial centers. The article puts emphasis on the civic character of both institutions and their role in shaping urban, regional, and national identities. Both of the discussed museums followed European models, having particularly close connections to the South Kensington Museum and the Imperial-Royal Museum of Art and Industry in Vienna and referring to it in their statutes and program activities; they also engaged in vibrant scientific exchange with institutions in the capital and other cities of the Empire and formed part of the imperial network of industrial museums. Nonetheless, the museum in Kraków and Lviv displayed uniquely local elements, developed thanks to the involvement of municipal associations, institutions, and residents.

${ }^{1}$ Praca naukowa finansowana w ramach programu Ministra Nauki i Szkolnictwa Wyższego pod nazwa Narodowy Program Rozwoju Humanistyki w latach 2017-2022, nr projektu $11 \mathrm{H} 16008784$. 
Słowa kluczowe: muzeum przemysłowe, wystawy, rzemiosło, kolekcjonerstwo, edukacja, kultura miejska

Keywords: industrial museum, exhibitions, crafts, collecting, education, urban culture

W drugiej połowie XIX w. w miastach Europy, Ameryki, a nawet w ośrodkach kolonialnych zakładane były muzea określane w języku polskim mianem przemysłowych ${ }^{2}$. Te ważne centra kultury, nauki, edukacji powstały w odpowiedzi na szybko postępującą industrializację, mechanizację i demokratyzację oraz niesione przez nie zagrożenia dla wysokiej jakości rzemiosła i tradycji kultury artystycznej. Miały one pielęgnować i promować wzornictwo skierowane do masowego odbiorcy, które byłoby oparte na najlepszych wzorcach historycznych, usiłując zarazem pogodzić tradycję z postępem. Muzea te były ważnym miejscem kreowania tożsamości zarówno miejskich, jak i imperialnych. W ówczesnej Europie ich działalność podszyta była ideą współzawodnictwa.

Instytucje takie zakładano również w ośrodkach prowincjonalnych, gdzie podobnie jak muzea metropolitarne były ważnym miejscem kreowania tożsamości miejskiej, odwołującej się jednak nie tyle do ambicji imperialnych i uniwersalnych, ile do kontekstu regionalnego i narodowego. $\mathrm{Na}$ znaczenie uniwersalnych modeli wystawienniczych w kreowaniu i legitymizacji lokalnych tożsamości w ostatniej ćwierci XIX i w pierwszych dziesięcioleciach XX w. zwróciła uwagę Marta Filipová, która zorganizowała konferencję poświęcona recepcji modelu wystaw światowych w prowincjonalnych ośrodkach imperiów ${ }^{3}$. Wnioski z tej konferencji można przełożyć również na fenomen muzeów przemysłowych zakładanych w tych ośrodkach, które współkształtowały odrębną tożsamość miejską i regionalną: w instytucji, która odwoływała się do przykładów metropolitarnych szczególna rola przypisywana była wystawom, eksponatom i wydarzeniom odwołujacym się do historii, tradycji regionu/ narodu, jego specyfice etnicznej, kulturowej, gospodarczej i krajobrazowej.

Pod koniec lat sześćdziesiątych i w pierwszej połowie lat siedemdziesiątych założone zostały trzy polskie muzea przemysłowe: Muzeum

${ }^{2}$ Literatura na temat tego zjawiska jest obszerna; por. m.in. Art and Design for All. The Victoria and Albert Museum, red. J. Bryant, London 2011; K. Curran, The Invention of the American Art Museum. From Craft to Kulturgeschichte 1870-1930, Los Angeles 2016, s. 1-51.

${ }^{3}$ Cultures of International Exhibitions 1840-1940. Great Exhibitions in the Margins, red. M. Filipová, Farnham 2015. 
Techniczno-Przemysłowe w Krakowie (1868), Muzeum Przemysłowe we Lwowie (1873) i Muzeum Rolniczo-Przemysłowe w Warszawie (1875). W zaborze pruskim nie było polskich inicjatyw tego typu. W Poznaniu dopiero w 1893 r. w ramach niemieckiego Muzeum Prowincjonalnego powstał dział rzemiosła artystycznego (Kunstgewerbeabteilung), który odzwierciedlał ważną zmianę, jaka zaszła w muzeach przemysłowych kręgu niemieckiego w ciagu pierwszego dwudziestolecia ich funkcjonowania. Z instytucji skupionych na wszelkich rodzajach wytwórczości rzemieślniczej i przemysłowej przekształciły się one wówczas w placówki odwołujące się do zasad i kanonów wypracowywanych przez kształtująca się w tym czasie dyscyplinę historii sztuki i skoncentrowane niemal wyłącznie na rzemiośle artystycznym ukazanym w perspektywie historycznej. Do jednej z najwcześniejszych niemieckich instytucji tego typu należało Muzeum Rzemiosł Artystycznych (Kunstgewerbe Museum) wydzielone w 1885 r. z Muzeum Prowincjonalnego w Gdańsku.

Choć wszystkie trzy polskie muzea przemysłowe wiele łączyło (ich społeczny i miejski charakter, szeroki zakres działalności, znaczenie pierwiastka narodowego, a także wzajemne kontakty i wymiana), to $\mathrm{w}$ tym artykule zajmę się jedynie instytucjami galicyjskimi. Obie należały bowiem do dużej sieci muzeów zakładanych w Austro-Węgrzech w ostatnich trzech dziesięcioleciach XIX w., z których centralnym i wzorcowym było C.K. Muzeum Sztuki i Przemysłu (K.K. Museum für Kunst und Industrie) w Wiedniu ${ }^{4}$. Wzorce płynace ze stolicy, kontakty z innymi należącymi do tej sieci muzeami w Cesarstwie, a także znaczenie wiedeńskich znajomości współtwórców muzeów w Krakowie i we Lwowie miały dla charakteru ich działalności znaczenie decydujacce.

W Austro-Węgrzech muzea przemysłowe zakładane były zarówno w regionach zindustrializowanych i miejskich, jak i w takich, które tak jak Galicja i Bukowina - były przeważnie wiejskie i w których postęp i migracje w pierwszym rzędzie zagrażały lokalnym tradycjom ludowym. Tym samym te instytucje miejskie stanowiły ważny łącznik z prowincja. Były to ponadto regiony różnorodne etnicznie i narodowo, co też miało swój wpływ na ich charakter. Choć oba analizowane muzea wzorowane były na przykładach zagranicznych, a w szczególności były blisko powiązane z instytucją wiedeńska, odwoływały się do jej statutów i programów, prowadziły z instytucjami w stolicy i innych ośrodkach Cesarstwa ożywiona wymianę naukowa, a także należały do sieci cesarskich muzeów przemysłowych, to każde z nich miało swój odrębny

${ }^{4}$ M. Rampley, Design Reform in the Habsburg Empire: Technology, Aesthetics and Ideology, „Journal of Design History” 23, 2010, nr 3, s. 247-264. 
rys lokalny, kształtowany dzięki zaangażowaniu miejskich stowarzyszeń i instytucji oraz obywateli.

Dotychczas w centrum zainteresowania badaczy znalazła się wczesna działalność Muzeum Techniczno-Przemysłowego. Poświęcono jej liczne artykuły i opracowania o charakterze monograficznym ${ }^{5}$. Ich baza źródłową jest zachowane szczątkowo archiwum tej instytucji ${ }^{6}$, obejmujące głównie materiały z okresu zaborów - roczne lub kilkuletnie sprawozdania z działalności kierowane do Rady Miasta Krakowa, projekty statutów, szczątkowa korespondencję dotycząca działalności, zbiorów muzealnych i bibliotecznych, której ważnym uzupełnieniem jest dziennik korespondencji wychodzącej z lat 1868-1885, księgę darów obejmująca lata 1870-1887 oraz wydawane przez Muzeum broszury (sprawozdania, statuty, ogłoszenia konkursów, programy wykładów, prospekty wydawnicze itp.) i poświęcone jego działalności artykuły prasowe ${ }^{7}$. W centrum uwagi znalazła się w szczególności postać założyciela instytucji, Adriana Baranieckiego, brytyjskie wzorce instytucji oraz zaprojektowany dla niej przez Franciszka Mączyńskiego i Tadeusza Stryjeńskiego gmach. Zbiory Muzeum - rozproszone dzisiaj między inne krakowskie instytucje (Muzeum Narodowe, Muzeum Etnograficzne, Akademia Sztuk Pięknych) - zostały opisane bardzo oględnie na podstawie rękopiśmiennych i drukowanych sprawozdań. Jak dotąd nie pokuszono się o rekonstrukcję zachowanej kolekcji oraz o szersze badania przeprowadzone na podstawie historycznych ksiag inwentarzowych i kartotek ${ }^{8}$.

Muzeum krakowskie uwzględnione zostało również w monografii Matthew Rampleya, Markiana Prokopovycha i Nóry Veszprémi, która analizuje wiedeńskie muzeum przemysłowe w szerokim kontekście społecznym, politycznym i narodowościowym ${ }^{9}$. Książka jest efektem projektu badawczego „Museums in Austria-Hungary 1864-1918”, prowadzonego na Uniwersytecie w Birmingham. Autorzy dużo miejsca poświęcili

5 Zob. zwł.: Z. Beiersdorf, Muzeum Techniczno-Przemystowe w Krakowie, „Rocznik Krakowski” 57, 1991, s. 129-164; P. Hapanowicz, Działalność Muzeum Techniczno-Przemystowego $w$ Krakowie $i$ jego likwidacja w latach 1949-1950, „Zarządzanie w Kulturze” 8, 2007, s. 43-62; M. Więcek, M. Dolińska, D. Tomkowicz, Zapomniane muzeum: Adrian Baraniecki i jego Muzeum Techniczno-Przemystowe 1868-1950, Kraków 2013.

${ }^{6}$ ANK, zespół Muzeum Przemysłu Artystycznego we Lwowie.

7 Zob. m.in. A. Bełcikowski, Dr. Adryan Baraniecki i jego Muzeum techniczno-przemystowe w Krakowie, „Tygodnik Ilustrowany”, 23 XI 1872, s. 250-251.

8 Przechowywane w Archiwum Muzeum Narodowego w Krakowie.

${ }^{9}$ M. Rampley, M. Prokopovych, N. Veszprémi, Liberalism, Nationalism and Design Reform in the Habsburg Empire. Museums of Design, Industry and Applied Arts, New York 2020. 
muzeom przemysłowym zakładanym w różnych ośrodkach Cesarstwa, wskazując na ich lokalną specyfikę oraz analizując ich związki z Wiedniem. Muzeum krakowskie zostało przez nich określone jako instytucja wyrastająca przede wszystkim z lokalnego kontekstu narodowo-politycznego, która rozwinęła się w rzeczywistości autonomii galicyjskiej i odzwierciedlała idee konserwatywnego pozytywizmu. Opierając się na dotychczasowej literaturze, zwrócili oni uwagę, że jest to jedno z nielicznych muzeów w Cesarstwie, które nie wzorowało się na muzeum wiedeńskim, lecz na londyńskim South Kensington Museum.

Muzeum Przemysłowe we Lwowie nie było jak do tej pory przedmiotem równie wnikliwych badań. W 1951 r. spuścizna tej instytucji (obejmująca oprócz zbiorów artystycznych również archiwum i instrumentarium, tzn. gabloty, plansze wystawiennicze czy katalog biblioteczny) połączona została z kolekcja Muzeum Towarzystwa Naukowego im. Tarasa Szewczenki, stając się podstawą ukraińskiego Muzeum Etnografii i Przemysłu Artystycznego we Lwowie z siedzibą w gmachu dawnej Galicyjskiej Kasy Oszczędności. Podczas II wojny światowej oraz w okresie powojennych reorganizacji część zbiorów Muzeum Przemysłowego zaginęła bądź została rozproszona pomiędzy inne ukraińskie instytucje muzealne i biblioteczne. W 2008 r. polskie Ministerstwo Kultury i Dziedzictwa Narodowego zainicjowało projekt badawczy poświęcony zbiorom dawnego Muzeum Przemysłowego, który ograniczył się jednak do opracowania katalogów dwóch waskich kolekcji Muzeum Etnografii i Przemysłu Artystycznego (zbiorów szkła europejskiego i plakatów polskich) ${ }^{10}$. Historia, okoliczności powstania i działalność Muzeum Przemysłowego nie była natomiast jak dotąd przedmiotem badań. Podstawa moich rozważań jest niewykorzystywana dotąd w literaturze, zachowana kompletnie korespondencja przychodząca Muzeum (obejmująca również bruliony odpowiedzi i listów wychodzących), którą pozostawiono w przedwojennym układzie (listy posegregowane sa w rocznych poszytach, w ramach których uporządkowane są chronologicznie) ${ }^{11}$.

W tym artykule przedstawię oba muzea jako ważne ośrodki miejskiego życia kulturalnego i społecznego. Skupię się w szczególności na różnorodności podejmowanych przez nie inicjatyw (znacznie

10 A.J. Kasprzak, H. Skoropadowa, Europejskie szkło od XVI do poczqtku XIX wieku $w$ zbiorach Muzeum Etnografii $i$ Przemystu Artystycznego Instytutu Narodoznawstwa Narodowej Akademii Ukrainy we Lwowie, Warszawa 2008; A.A. Szablowska, M. Seńkìw, Plakat polski ze zbiorów Muzeum Etnografii i Przemystu Artystycznego Instytutu Narodoznawstwa Narodowej Akademii Ukrainy we Lwowie, Warszawa 2009.

${ }_{11}$ Przechowywane w Muzeum Etnografii i Przemysłu Artystycznego we Lwowie (dalej: MEiPA). 
wykraczającej poza aktywność, którą dziś kojarzy się z muzeami) oraz na analizie społecznego zaangażowania w ich działalność. Interesować mnie będzie pierwszy okres funkcjonowania obu instytucji, który ograniczony jest rokiem 1914. Wraz z wybuchem wojny oba muzea praktycznie zaprzestały swojej działalności, wówczas też znacznie osłabiła się dotychczasowa sieć kontaktów, która przerwana została ostatecznie wraz z powstaniem państwa polskiego. W szczególności skupię się na okresie ograniczonym umowną datą ok. 1900 r. Wówczas w ramach obu instytucji rozpoczęto dyskusję nad przeformułowaniem ich celów i funkcji. Podobnie jak w przypadku wielkich instytucji w Londynie i Wiedniu, do których się one odwoływały, pierwsze lata działalności galicyjskich muzeów były czasem wykuwania się koncepcji muzeum, jego kolekcji, prowadzonej w nim edukacji, a także największego zaangażowania obywatelskiego w ich działalność. W ostatniej ćwierci XIX w. poszczególne gałęzie nauki, instytucje badawcze i edukacyjne dopiero się kształtowały, co odzwierciedlone jest w szeroko zakrojonej działalności tych muzeów oraz ich wielopłaszczyznowej współpracy z miejskimi i społecznymi instytucjami i organizacjami, elitami gospodarczymi, politycznymi, naukowymi i kulturalnymi, a także z licznymi rzemieślnikami i przedsiębiorcami. Zarówno muzeum lwowskie, jak i krakowskie należały ponadto do pierwszych tego typu instytucji w obu ośrodkach. Pod koniec XIX w. funkcjonały już one w zupełnie innym, znacznie bardziej rozbudowanym pejzażu kulturalnym i muzealnym.

\section{Wystawy światowe i początki galicyjskich muzeów przemysłowych}

Powstanie i rozwój muzeów przemysłowych w większych i mniejszych ośrodkach miejskich świata zachodniego było jednym z ważnych elementów dziewiętnastowiecznej kultury, który należy łączyć z fenomenem wystaw uniwersalnych ${ }^{12}$. Organizowane $\mathrm{w}$ drugiej połowie stulecia w kilkuletnich interwałach w najważniejszych metropoliach Europy, a pod koniec stulecia również Ameryki i Australii, stanowiły pokaz najnowszych osiagnieć techniki, przemysłu, wynalazków, osiagnięć naukowych i kulturalnych poszczególnych imperiów i państw.

${ }^{12}$ Literatura na temat wystaw światowych jest bardzo obszerna; por. m.in. P. Greenhalgh, Ephemeral Vistas. The Expositions Universelles, Great Exhibitions and World's Fairs, 1851-1939, Manchester 1988; J.T. Busch, C.L. Futter, R. Lee Błaszczyk, Inventing the Modern World. Decorative Arts and the World's Fairs, 1851-1939, New York 2012. 
Otwarte przez kilka miesięcy, odwiedzane licznie przez ludzi z całego świata, miały ogromny wpływ na ówczesną świadomość, postrzeganie świata, naukę, kulturę czy rozrywkę. Wystarczy wspomnieć, że wnętrza Crystal Palace - pawilonu ekspozycyjnego wybudowanego ze szkła i stali w Hyde Parku dla pomieszczenia pierwszej wystawy światowej zorganizowanej w $1851 \mathrm{r}$. w Londynie - odwiedziło ponad 6 mln ludzi z różnych zakątków świata. Kultura wystaw uniwersalnych wykraczała znacznie poza ramy wielkich metropolii, pretendujacych do miana stolic ówczesnego świata zachodniego czy rywalizujących między sobą także na polu kultury, nauki i przemysłu wielkich imperiów. W tym okresie również w mniejszych, znajdujących się nieraz na peryferiach ośrodkach miejskich, które trudno łaczyć z gwałtowną industrializacja, organizowano wystawy w znacznie mniejszej, regionalnej skali, które odwoływały się do wzorców wystaw uniwersalnych (od efemerycznych pawilonów wystawowych, zbliżone sformułowanie zasad wystawienniczych i ankiet dla wystawców po organizację podobnych imprez towarzyszacych). Ich celem było z jednej strony stymulowanie rozwoju i współzawodnictwa lokalnych rzemiosł i przedsiębiorczości, z drugiej - budowanie tożsamości miejskich i regionalnych ${ }^{13}$. Zarówno wystawy lokalne, jak i te uniwersalne angażowały rzesze lokalnych stowarzyszeń i instytucji, przedsiębiorców, rzemieślników, artystów, kolekcjonerów, którzy współuczestniczyli w ich organizacji.

Wystawy światowe były ważnym elementem kreowania tożsamości imperialnych i narodowych: eksponaty porządkowane były wedle różnych kategorii w pawilonach lub salach narodowych, które stanowiły starannie wypracowaną wizytówkę państwa lub imperium. Wystawa w Crystal Palace nawiązywała bezpośrednio do zorganizowanej w 1849 r. w Paryżu Exposition des Produits de l'Industrie Française, a zaaranżowana w 1855 r. w Paryżu druga wystawa uniwersalna była francuską odpowiedzią na pokaz w Crystal Palace. Tym samym na tych pierwszych wystawach główna rywalizacja rozgrywała się między Francją i Wielką Brytanią. To rozbudzony na wystawach duch brytyjsko-francuskiego współzawodnictwa stał za utworzeniem w $1852 \mathrm{r}$. Museum of Manufactures, przyszłego South Kensington Museum, zupełnie nowego rodzaju muzeum, prototypu kilkudziesięciu tego typu instytucji, zakładanych przede wszystkim w krajach niemieckich i Stanach Zjednoczonych. Powołana przez księcia Alberta instytucja z jednej strony miała doprowadzić do ważnego przewrotu i wypromować brytyjskie wzornictwo, z drugiej - stanowić doskonalszy brytyjski odpowiednik nowego

${ }^{13}$ Cultures of International Exhibitions... 
rodzaju muzeum zapoczątkowanego w Paryżu, a ilustrującego narodowa sztukę i kulturę poprzez rozwój rzemiosła i ornamentyki.

Wystawy światowe stanowiły ważny impuls do założenia obu omawianych galicyjskich instytucji. Muzeum Techniczno-Przemysłowe w Krakowie powstało z inicjatywy jednej osoby - pochodzącego z Jarmoliniec na Podolu lekarza, społecznika i emigranta popowstaniowego, Adriana Baranieckiego (1828-1891) ${ }^{14}$. Po upadku powstania styczniowego wyemigrował on do Londynu i Paryża, gdzie z dużym zainteresowaniem śledził ruch wystawienniczy i muzealny, a zwłaszcza zorganizowana z inicjatywy Napoleona III od kwietnia do listopada $1867 \mathrm{r}$. Wystawę Światowa, drugie przedsięwzięcie tego rodzaju, które miało miejsce w Paryżu. Wystawę poprzedziły kilkuletnie, trwające od $1864 \mathrm{r}$. przygotowania, liczne zebrania, dyskusje, a wszystko było szeroko omawiane w prasie. Francuskie i brytyjskie znajomości i kontakty, o których Baraniecki wspomina w liście do Rady Miasta Krakowa z 1868 r., musiały zostać zawiązane w tym okresie ${ }^{15}$. Stworzenie kolekcji ok. 5 tys. przedmiotów, które stały się zalążkiem krakowskiego muzeum, stało się możliwe dzięki ofiarności niewymienionych z nazwiska prywatnych darczyńców z Francji i Anglii, wystawców i członków komitetów organizacyjnych poszczególnych sekcji wystawy z $1867 \mathrm{r}$. oraz Konserwatorium Sztuk i Rzemiosł w Paryżu ${ }^{16}$. Ten zbiór uzupełnił obiekty kupowane przez Baranieckiego wytrwale w Londynie i Paryżu na wystawach, pokazach lub bezpośrednio od przedsiębiorców.

Muzeum Przemysłowe we Lwowie założone zostało przy okazji wystawy światowej zorganizowanej w $1873 \mathrm{r}$. w Wiedniu ${ }^{17}$. Tym razem inicjatywa miała charakter szerszy. Wyszła ze strony lwowskiej Izby Rękodzielniczej, jednej z kilku lwowskich instytucji zaangażowanych $\mathrm{w}$ przygotowanie galicyjskiej sekcji wystawy ${ }^{18}$. Na zebraniu, w którym uczestniczyło kilkudziesięciu przedstawicieli lwowskich korporacji rzemieślniczych i przemysłowych, galicyjskich przedsiębiorców, działaczy społecznych, politycznych i kulturalnych, ustalono, że organizowana

${ }^{14}$ P. Hapanowicz, Adrian Baraniecki - prekursor polskiego muzealnictwa przemystowego, „Muzealnictwo” 57, 2016, s. 16-25.

15 ANK, Muzeum Przemysłu Artystycznego w Krakowie, 1, Założenie Muzeum Techniczno-Przemysłowego, Adrian Baraniecki do Rady Miasta Krakowa, Kraków, 4 IV 1868 r., k. 1.

${ }^{16}$ Może tu chodzić o École des arts appliqués à l'industrie lub École supérieure des arts appliqués Duperré.

${ }_{17}$ MEiPA, Korespondencja Muzeum Przemysłowego, 1873/1874 r.

${ }_{18}$ Czterdziestolecie Izby Stowarzyszeń rękodzielniczych we Lwowie, oprac. J. Starkel, Lwów 1916, s. 16. 
w Wiedniu ekspozycja stanowi wielką szansę na stworzenie podwalin kolekcji planowanego muzeum. Izba ogłosiła subskrypcje na zakup eksponatów, udało jej się również uzyskać dotację od Sejmu Krajowego, równie ważne okazały się prywatne i instytucjonalne kontakty. Szczególną rolę w koordynacji zakupów odegrał Włodzimierz Dzieduszycki (1825-1899), przewodniczący galicyjskiego komitetu wystawy, który zdołał uzyskać liczne dary od wystawców, wiedeńskich fabrykantów, a także skłonić instytucje wiedeńskie i ministerstwa do wzbogacenia planowanej kolekcji muzeum ${ }^{19}$. Istotne było również włączenie lwowskiej instytucji do programu zakupów Ministerstwa Przemysłu i Handlu na wystawie wiedeńskiej przeznaczonych dla muzeów przemysłowych zakładanych w Cesarstwie. Trzon kolekcji oparty został także na zakupach, których dokonano na wystawie o charakterze krajowym (lokalnym): Wystawie Przemysłowo-Rolniczej zorganizowanej w 1874 r. na polach Ujazdowskich, prezentującej dorobek techniczny, naukowy i rolniczy Królestwa Polskiego ${ }^{20}$. Wiele eksponatów warszawskich, podobnie jak w przypadku tych wiedeńskich, trafiło do Lwowa jako dary. Ofiarodawcami byli mieszkańcy Warszawy i obywatele Królestwa Polskiego, Pelagia Branicka z Zamoyskich przekazała np. zakupione na Wystawie Przemysłowo-Rolniczej ryciny i juty.

W następnych latach obie instytucje inicjowały lub aktywnie uczestniczyły w organizacji wystaw krajowych, galicyjskich sekcji na wystawach światowych czy udziału indywidualnych wytwórców lub przedsiębiorców w wystawach na całym świecie. Każda $\mathrm{z}$ nich była ponadto okazją do poszerzania zbiorów, a na zakupy asygnowane były specjalne fundusze.

\section{Muzea przemysłowe w Krakowie i we Lwowie jako projekty miejskie i obywatelskie}

Baraniecki w listach skierowanych do Rady i prezydenta miasta Krakowa przedstawił swój zamysł planowanego muzeum jako zarządzanej kolegialnie instytucji miejskiej ${ }^{21}$. Muzeum miał kierować komitet oraz powoływany przez prezydenta miasta dyrektor. Pierwszym dyrektorem został Baraniecki, który ponadto otrzymał obywatelstwo miasta, w skład komitetu zaś, zgodnie ze statutem, weszli reprezentanci prezydenta

${ }^{19}$ Dzięki jego staraniom np. nawiązano kontakty z Muzeum Orientalnym w Wiedniu.

${ }^{20}$ Czterdziestolecie Izby Stowarzyszeń..., s. 16.

${ }_{21}$ ANK, Muzeum Przemysłu Artystycznego w Krakowie, 1, Założenie Muzeum Techniczno-Przemysłowego, Adrian Baraniecki do Rady Miasta Krakowa, Kraków, 4 IV 1868 r., k. 1. 
i Rady Miejskiej, Instytutu Technicznego, krakowskiego Towarzystwa Rolniczego i krakowskiej Izby Rzemieślniczej22. Tym samym Muzeum Techniczno-Przemysłowe pomyślane było jako element szerzej zakrojonych projektów, które w centrum uwagi stawiały rozwój przemysłu oraz rękodzieła w Krakowie i Galicji. W ich wyniku w ciagu kilku lat w Krakowie założone zostały m.in. nowe instytucje edukacyjne i naukowe. Zmodyfikowany w $1884 \mathrm{r}$. statut Muzeum odzwierciedlał te zmiany: odtą w skład komitetu muzealnego obok reprezentantów miasta wchodzić mieli członkowie Akademii Sztuk Pięknych (wydzielonej w 1873 r. ze struktury Instytutu Technicznego Szkoły Sztuk Pięknych), powołanego w 1878 r. C.K. Instytutu Techniczno-Przemysłowego, profesor katedry historii sztuki założonej w 1882 r. na Uniwersytecie Jagiellońskim i reprezentant Izby Handlowo-Przemysłowej ${ }^{23}$. Nowy statut odzwierciedlał zarazem ewoluująca koncepcję Muzeum, które w 1884 r. stało się placówką edukacyjną i naukowa, a w centrum jego zainteresowania znalazły się sztuka i rzemiosło artystyczne. Zgodnie z zawartymi w nim uregulowaniami przedstawiciele rzemieślników mieli mieć w komitecie tylko głos doradczy, a kwestie związane z promocją przemysłu i ogólnym rozwojem technologicznym zeszły na dalszy plan.

Muzeum Przemysłowe we Lwowie od samych początków było inicjatywą kolegialna - Izba Rzemieślnicza zadanie stworzenia nowej instytucji powierzyła komitetowi założycielskiemu, w skład którego weszli najwięksi entuzjaści tego projektu: przedsiębiorcy, politycy, inżynierowie, ziemianie, kolekcjonerzy ${ }^{24}$. Podobnie jak w Krakowie, stałe finansowanie oraz ciagłość działalności miało zagwarantować miasto, które otrzymało najwyższe kompetencje zarządcze i nadzorcze ${ }^{25}$. Prywatni ofiarodawcy, którzy przekazali na rzecz Muzeum sumę co najmniej 5 tys. zł lub jej odpowiednik w eksponatach, otrzymywali tytuł i prerogatywy założycieli, w tym m.in. dożywotnie miejsce w jego Radzie Nadzorczej. W skład tego kolegialnego ciała wchodziło ponadto piętnastu członków wybieranych na trzyletnie kadencje. Wszyscy musieli być obywatelami Lwowa. Podobnie jak w Krakowie, wysuwani oni byli przez lwowskie instytucje zaangażowane w rozwój przemysłu, rzemiosła i nowoczesnej edukacji. Dwunastu reprezentantów desygnowało miasto

${ }^{22}$ A. Szczerski, Wzorce tożsamości. Recepcja sztuki brytyjskiej w Europie Środkowej około roku 1900, Kraków 2002, s. 215-219.

${ }^{23}$ ANK, Muzeum Przemysłu Artystycznego w Krakowie, 2, Organizacja, Statut Muzeum Techniczno-Przemysłowego w Krakowie zatwierdzony uchwałą Rady miejskiej z dnia 3/7 1884, k. 1-3.

${ }^{24}$ Czterdziestolecie Izby Stowarzyszeń..., s. 15.

${ }_{25}$ Statut Miejskiego Muzeum Przemysłowego we Lwowie, [Lwów 1874]. 
(spośród których siedmiu miało być przemysłowcami bądź rzemieślnikami), po jednym reprezentancie miały Wydział Krajowy, Izba Rzemieślnicza i Akademia Techniczna. W 1888 r. model ten został lekko zmodyfikowany, by zapewnić miejsce w Radzie osobom najbardziej zaangażowanym w działalność Muzeum - Włodzimierzowi Dzieduszyckiemu i Ludwikowi Wierzbickiemu (1834-1912) ${ }^{26}$. Odtąd na wniosek Rady miasto mogło powołać członków dożywotnich, którzy pełnili role doradcze. Ponadto skład Rady poszerzono do siedemnastu członków, by, jak to miało miejsce cztery lata wcześniej w Krakowie, zapewnić miejsca dla reprezentantów nowo założonych lwowskich instytucji o zbliżonym profilu działalności oraz tych instytucji, z którymi w międzyczasie nawiazano współpracę: C.K. Szkoły Politechnicznej, Towarzystwa Politechnicznego, Galicyjskiej Kasy Oszczędności, Izby Handlowej i Przemysłowej.

Jak zauważył Andrzej Szczerski, kolegialny model zarządczy galicyjskich muzeów przemysłowych wzorowany był na brytyjskich muzealnych radach powierniczych ${ }^{27}$. Warto przy tym podkreślić, że był to jednocześnie model, który doskonale pasował do tych dwóch instytucji, ich ewoluujacej koncepcji, wreszcie i warunków, w jakich mogły one funkcjonować.

Skromne środki i lokale na prowadzenie działalności oba muzea otrzymały od miasta, niewielkie dotacje asygnowane były również przez Wydział Krajowy i, okazjonalnie, przez C.K. Ministerstwo Handlu i Przemysłu. Środków tych nigdy nie było jednak dość, a rozwój i działalność obu instytucji nie byłyby możliwe bez zaangażowania obywatelskiego. Statut Muzeum Przemysłowego przewidywał przyjmowanie darów i zapisów od zakładów i korporacji przemysłowych, stowarzyszeń i osób prywatnych, a ich nazwiska, razem z tymi założycieli, zapisywane były w specjalnej księdze, która wystawiona była na widok publiczny we wnętrzach Muzeum. Pierwsze fundusze, przeznaczone na zakup eksponatów na Wystawie Powszechnej w Wiedniu, zostały zebrane dzięki składkom wśród członków Izby Rzemieślniczej ${ }^{28}$. Kwota 6 tys. zł ofiarowana przez krawca Franciszka Bałutowskiego (1813-1886) była wyjątkowa na tle znacznie skromniejszych donacji. Ponadto większe sumy na fundusz żelazny, a w przyszłości siedzibę Muzeum ofiarowali wpływowi przedstawiciele galicyjskiego ziemiaństwa czy arystokracji: Leon Sapieha (1803-1878), Karol Lanckoroński (1848-1933; który wspierał większość galicyjskich instytucji naukowych i muzealnych), Izabela

\footnotetext{
${ }^{26}$ Statut Miejskiego Muzeum Przemystowego we Lwowie, [Lwów 1888].

27 A. Szczerski, dz. cyt.

${ }^{28}$ Czterdziestolecie Izby Stowarzyszeń..., s. 16.
} 
Dzieduszycka (1819-1893) i Karol Jabłonowski (1807-1885). Liczne były też dary eksponatów, materiałów bibliotecznych i mebli ekspozycyjnych ${ }^{29}$. Dary te były jednak zazwyczaj niewielkie (najczęściej kilka przedmiotów) i miały charakter jednorazowy, wśród darczyńców znajdziemy jednak i takich, którzy wytrwale przez całe życie zasilali zbiory Muzeum. Należał do niech Włodzimierz Dzieduszycki, który sam prowadził we Lwowie prywatne muzeum o częściowo zbliżonym profilu. Zainaugurowane w 1880 r. i ofiarowane narodowi w obecności Franciszka Józefa I Muzeum Przyrodnicze im. Dzieduszyckich podzielone było na siedem działów, w większości poświęconych faunie, florze oraz geologii Galicji. Najmłodszy dział, założony po wiedeńskiej wystawie światowej, w centrum uwagi stawiał etnografię regionu, a w kolekcjonerstwie szczególny nacisk położony był na wyroby przemysłu domowego. Dzieduszycki podczas wystaw krajowych i powszechnych nabywał eksponaty do obu instytucji ${ }^{30}$, do Muzeum Przemysłowego trafiały również przedmioty (nieraz otrzymane w darze), które nie pasowały do profilu jego Muzeum Przyrodniczego ${ }^{31}$. O dary u przedstawicieli ziemiaństwa i arystokracji czy u właścicieli fabryk i zakładów rzemieślniczych zabiegali osobiście członkowie komitetu, np. w 1875 r. u Artura Potockiego z Krzeszowic, prosząc o eksponaty z jego kopalń znajdujących się w okolicach Tenczyna wraz z objaśnieniami ${ }^{32}$.

Ważna grupę ofiarodawców stanowili przedsiębiorcy, rzemieślnicy i handlarze, dla których Muzeum Przemysłowe, licznie zwiedzane przez obywateli ziemskich i miejskich, było dobrym miejscem na promocję własnej oferty. Podobnie jak na wystawach przemysłowych, mogli oni swoich eksponatów tylko użyczać i wystawiać obok nich cenniki oraz prospekty reklamowe. Tego typu ekspozycje wyodrębnione były zreszta w statucie Muzeum, który wśród celów instytucji przewidywał organizację „wystaw przedmiotów sztuki, rękodzielnictwa i przemysłu, będących własnością osób prywatnych, korporacji przemysłowych, rękodzielniczych oraz zakładów publicznych i prywatnych krajowych, również

\footnotetext{
${ }^{29}$ Por. MEiPA, Korespondencja Muzeum Przemysłowego, 1873/1874 r.

${ }^{30}$ M.in. na Światowej Wystawie w Paryżu w 1878 r., na której był komisarzem wystawy austriackiej.

${ }^{31}$ W ten sposób w 1876 r. do zbiorów Muzeum Przemysłowego trafił zbiór bursztynów z Bukowiny wraz z ich szczegółowym opisem geologicznym, który został przesłany w darze do Muzeum im. Dzieduszyckich przez Józefa Zgrzebnego, Polaka zatrudnionego w Głównym Urzędzie Mierniczym w Wiedniu; por. MEiPA, Korespondencja Muzeum Przemysłowego, 1878 r., Włodzimierz Dzieduszycki do Komitetu Muzeum Przemysłowego, Wiedeń, 17 V 1878 r.

${ }^{32}$ MEiPA, Korespondencja Muzeum Przemysłowego, 1875 r., Rada Nadzorcza Muzeum Przemysłowego do Artura Potockiego, Lwów, 20 IX 1875 r.
} 
wzorowych wyrobów pojedynczych rękodzielników i przemysłowców wraz z cennikami”33. Stąd Karol Lewicki, właściciel największego lwowskiego składu porcelany, chętnie ofiarował na ekspozycję przykłady swojej oferty wyrobów fajansowych. Dla przedsiębiorców, rzemieślników i artystów austriackich dar do Muzeum Przemysłowego był również formą reklamy i budowania prestiżu: na wniosek Rady Nadzorczej byli oni wzmiankowani w prasie lwowskiej i wiedeńskiej oraz otrzymywali oficjalne podziękowania od ministra handlu i przemysłu. W ten sposób w zbiorach Muzeum Przemysłowego znalazły się m.in. odlewy gipsowe i rysunki ornamentów Opery Wiedeńskiej, ofiarowane przez ich autora, Franza Schönthalera (1821-1904). Wśród darczyńców znajdziemy również kolekcjonerów, artystów i badaczy, np. malarza i etnografa amatora Seweryna Obsta (1847-1917) czy fotografa i kolekcjonera z Kamieńca Podolskiego, Michała Greima (1828-1911).

Zbiory Muzeum Techniczno-Przemysłowego również powiększały się dzięki darom. Podobnie jak w przypadku instytucji lwowskiej, eksponaty wysyłane były głównie przez Polaków, a ich nazwiska, skrzętnie odnotowane nie tylko w inwentarzach ${ }^{34}$, na kartach naukowych ${ }^{35}$, ale też w osobnym spisie darów, stanowią odzwierciedlenie ważnych lokalnych i ponadzaborowych sieci kontaktów ${ }^{36}$. Wśród ofiarodawców odnajdziemy zarówno członków krakowskiej śmietanki kulturalnej i naukowej: fotograf Awit Szubert (1837-1919), profesor antropologii na Uniwersytecie Jagiellońskim Izydor Kopernicki (1825-1891), publicysta i korespondent Akademii Umiejętności Napoleon Ekielski (1810-1891), malarz Jan Matejko (1838-1893), ekonomista Karol Langie (1814-1889) czy profesor zoologii na Uniwersytecie Jagiellońskim Maksymilian Nowicki (1826-1890), jak i ważnych animatorów nauki i kultury z Lwowa i Warszawy, których naukowe i kulturalne kontakty w Krakowie rozciagały się też na Uniwersytet Jagielloński, Akademię Umiejętności czy Muzeum Narodowe: Włodzimierz Dzieduszycki czy Konstanty (18461897) i Aleksander (1814-1871) Przezdzieccy. Podobnie jak w przypadku Muzeum Przemysłowego, wśród ofiarodawców byli liczni rzemieślnicy i przemysłowcy, z których niektórzy, jak wzmiankowany już fotograf z Kamieńca Podolskiego Michał Greim, przekazywali swojej wytwory do obu instytucji. Katalog zawiera też wiele nazwisk polskich emigrantów zamieszkałych w europejskich centrach, którzy wysyłali do

${ }^{33}$ Statut Miejskiego Muzeum Przemysłowego we Lwowie... [1874], s. 7.

${ }_{34}$ Przechowywanych dziś w Archiwum Muzeum Narodowego w Krakowie.

${ }_{35}$ Przechowywanych dziś w Archiwum Muzeum Narodowego w Krakowie.

${ }^{36}$ ANK, Muzeum Przemysłu Artystycznego w Krakowie, 173, Księga eksponatów przekazanych do Muzeum jako dary (1870-1887). 
Krakowa nowinki technologiczne i przemysłowe. Powstaniec listopadowy Seweryn Gałęzowski (1801-1878), który od lat pięćdziesiątych był lekarzem w Paryżu, ofiarował druty telegraficzne, powstaniec styczniowy Bronisław Radziszewki (1838-1914), pracujacy jako asystent i preparator chemiczny na Uniwersytecie w Lowanium, regularnie wysyłał publikacje i broszury dotyczace nowości ze świata medycyny i chemii, a Stanisław Kostka Jasiński (zm. 1887), powstaniec styczniowy, który w Brukseli był pracownikiem firmy bankierskiej Caumont, ofiarował okazowe wyroby belgijskich fabryk.

Inwentarz darów Muzeum Techniczno-Przemysłowego i korespondencja Muzeum Przemysłowego ujawniaja, jak ważne dla tworzenia zbiorów były wymiany między krakowskimi i lwowskimi instytucjami naukowymi i kulturalnymi, które prowadziły działalność kolekcjonerska, w szczególności z gabinetami Uniwersytetu Jagiellońskiego, Muzeum Narodowym w Krakowie i Akademią Umiejętności. Szczególną i liczna grupę ofiarodawców obu muzeów stanowili mieszkańcy prowincji - ziemianie, nauczyciele czy lekarze - którzy amatorsko parali się kolekcjonerstwem oraz badaniem przyrody i etnografii okolic, które zamieszkiwali. W ten sposób zbiory obu instytucji zasilone zostały w ważne eksponaty o charakterze etnograficzno-przyrodniczym. Muzeum Techniczno-Przemysłowe w ciagu kilkunastu lat zdołało w ten sposób skompletować ważną kolekcję strojów włościańskich reprezentujacych cały obszar historycznej Rzeczypospolitej, szczególną specjalizacja Muzeum Przemysłowego były zaś stroje i wyroby rzemieślnicze z Huculszczyzny.

\section{Między miastem, prowincją a europejskimi stolicami: działalność galicyjskich muzeów przemysłowych}

Plany postawienia nowoczesnego, zbudowanego specjalnie na potrzeby muzeum gmachu były ważnym elementem w programach założycielskich zarówno lwowskiej, jak i krakowskiej instytucji. W wyniku subskrypcji przeprowadzonej w 1873 r. na cele planowanego muzeum we Lwowie, komitetowi założycielskiemu udało się zebrać największe sumy właśnie na budowę siedziby. Z jednej strony odrębny gmach miał zapewnić instytucji trwałość i przestrzeń do działalności, z drugiej ofiarodawcy niewatpliwie byli świadomi faktu, że nowoczesny, wykorzystujacy nowatorskie materiały i rozwiązania techniczne, awangardowe wyroby krajowych manufaktur i projekty obiecujących architektów i artystów gmach był jednym z wyróżników instytucji muzeum przemysłowego, a jego ciekawa architektura oraz oferta wystawiennicza, 
naukowa i edukacyjna były ważnymi elementami nowoczesnego miasta. Londyńskie Museum of Manufactures już w 1857 r. zostało przeniesione z prowizorycznych wnętrz w Marlborough House do specjalnie wybudowanego i w następnych latach rozbudowywanego gmachu w dzielnicy South Kensington. Budynek, jego dekoracje, wnętrza i elementy (od tapet po krzesła czy gabloty) miał sam w sobie być wizytówką brytyjskiego wzornictwa: poszczególne jego elementy projektowali związani z Muzeum i szkołą wzornictwa architekci i artyści, dla których stał się on polem do eksperymentów i zademonstrowania własnego talentu. W elementach architektonicznych, dekoracyjnych i wyposażenia wykorzystywano nowinki technologiczne i popularne wyroby brytyjskich manufaktur, m.in. glazurowane płytki, elementy stalowe, boazerie i witraże. W gmachu wzniesionym w dzielnicy South Kensington po raz pierwszy wykorzystano też nowe, wręcz rewolucyjne rozwiąznia. W 1857 r. Muzeum posiadało już duża, specjalnie na ten cel przeznaczona salę wykładowa, w następnych latach dobudowano doń m.in. trzy zaskakujące bogactwem dekoracji i nowoczesnością sale restauracyjne, a także nowoczesne toalety. W South Kensington po raz pierwszy zastosowano również oświetlenie gazowe, dzięki czemu mogło być ono otwarte również w godzinach wieczornych. Zainaugurowany w $1871 \mathrm{r}$. gmach C.K. Muzeum Sztuki i Przemysłu był pierwszym budynkiem muzealnym, który stanął w obrębie właśnie rozplanowywanego Ringu, szerokiej alei z budynkami użyteczności publicznej, monumentalnymi kamienicami czynszowymi i parkami, która powstała w miejscu zniesionych murów miejskich. Tym samym Muzeum stało się ważnym elementem nowoczesnej przebudowy Wiednia, a jego neorenesansowy gmach wizytówką miasta.

Ważną cechą gmachów muzeów londyńskiego i wiedeńskiego była ich przestronność, która umożliwiła pomieszczenie zaplanowanej na wielką skalę i zarazem niezwykle różnorodnej działalności. Zachowany w korespondencji Muzeum Przemysłowego pierwszy Program dla projektu na budowe muzeum przemystowego $i$ szkoty przemystowej autorstwa oficjalnego architekta miejskiego Juliusza Hochbergera (1845-1905), skreślony w 1876 r., a więc w początkach działalności tej instytucji, pokazuje, że galicyjskie muzea pomyślane były $\mathrm{z}$ równie wielkim rozmachem ${ }^{37}$. Powiązane ze soba gmachy muzeum i szkoły stanąc miały na działce na placu Castrum (dzisiejsza ulica Niski Zamek), a ich fasady główne miały wychodzić na ulicę Teatralna. Styl i materiał wykonania obu

${ }^{37}$ MEiPA, Korespondencja Muzeum Przemysłowego, 1876 r., Program dla projektu na budowę muzeum przemysłowego i szkoły przemysłowej we Lwowie. 
budynków nie został określony w Programie, zakładano jednak, że będą one zaopatrzone $\mathrm{w}$ nowoczesną infrastrukturę: podłączone do wodociagów, wyposażone w centralne ogrzewanie i wentylację, oświetlenie gazowe oraz zabezpieczenia przeciwpożarowe. Ponadto, na wzór muzeów londyńskiego i wiedeńskiego, jednopiętrowy gmach zaopatrzony miał być w duży, 300-metrowy, przeszklony dziedziniec arkadowy. W Programie szczegółowo określone były niezbędne pomieszczenia, ich wielkość, położenie i funkcja. Na działalność ekspozycyjna przeznaczonych miało być dwanaście sal, w tym osiem na piętrze na pomieszczenie stałej ekspozycji, a cztery na parterze na wystawy czasowe. Dwie odrębne sale umieszczone na parterze, do których miało prowadzić osobne wejście, przeznaczone były na bazar, czyli pokazy produktów rękodzielniczych do sprzedaży. Na parterze znajdować się również miała 120-metrowa sala na odczyty publiczne. Umieszczona na tej kondygnacji biblioteka z osobną pracownią rysunkową oraz znajdujące się w podziemiu dwie sale z odlewami gipsowymi miały być wykorzystywane do celów edukacyjnych i podobnie jak pracownie galwanoplastyczna, fotograficzna i warsztat stanowiły przedłużenie pracowni i warsztatów, które miały być umieszczone w ramach poszczególnych wydziałów w budynku szkoły. Program, którego koszty wyceniono na 400 tys. zł, nie został wówczas zrealizowany, a Muzeum starało się rozwijać szeroko zakreślona w statucie działalność w udostępnionych przez miasto salach ratusza i w wynajmowanych okazjonalnie wnętrzach. Gmachy Muzeum Przemysłowego i Szkoły Przemysłowej powstały w następnych dziesięcioleciach działalności obu instytucji i na podstawie planów dopasowanych do ich ewoluujących funkcji. W latach 1890-1892 przy ulicy Teatralnej 17 wzniesiono gmach Szkoły Przemysłowej według projektu Gustawa Bisanza, w latach 1890-1903 zaś przy ulicy Hetmańskiej 20 jako osobne i niepowiązane $\mathrm{z}$ nim przedsięwzięcie architektoniczne zbudowany został gmach Muzeum wedle projektu Leandra Marconiego i Józefa Kajetana Janowskiego. Choć nie jest znany projekt gmachu dla Muzeum Techniczno-Przemysłowego z początkowego okresu jego działalności, można przypuszczać, że wyglądałby on podobnie. Statut tej instytucji zakładał stworzenie zbiorów, biblioteki, laboratoriów, odlewni gipsowej oraz szkoły rysunku i modelowania, prowadzone miały być też odczyty i działalność wydawnicza ${ }^{38}$.

Oba muzea, choć przez pierwsze dziesięciolecia funkcjonowały w prowizorycznych i zbyt ciasnych na potrzeby ich działalności wnętrzach (krakowskie w należącym do miasta klasztorze pofranciszkańskim,

\footnotetext{
${ }^{38}$ Za: Z. Beiersdorf, dz. cyt., s. 133.
} 
a lwowskie w ratuszu), od samego początku stały się ważnym centrum miejskiego życia kulturalnego i naukowego.

Edukacja należała do najważniejszych i najprężniej rozwijających się form działalności obu muzeów przemysłowych. W 1860 r. w całym Cesarstwie zaczęła obowiazzywać ustawa przemysłowa (Gewerbeordnung) z 29 XII 1859 r., która uwolniła rzemiosło i handel spod surowych regulacji cechowych, zniosła dotychczasowy oparty na cechach system organizacji i kształcenia rzemieślników oraz wymusiła zupełnie nowy system zrzeszania się poszczególnych zawodów w korporacjach. W 1868 r. we Lwowie założona została Izba Rękodzielnicza, która zrzeszając wszystkie działające w mieście korporacje, miała reprezentować interesy miejscowych rzemieślników, dbać o jakość ich produkcji oraz edukacji ${ }^{39}$. Powołanie Muzeum Przemysłowego, które miało przyczynić się do wzrostu jakości edukacji rzemieślniczej, było jedną najwcześniejszych i najważniejszych inicjatyw Izby. Projekt tego przedsięwzięcia konsultowany był m.in. z dyrektorem muzeum wiedeńskiego, Rudolfem Eitelbergerem (1817-1885), który zasugerował jednocześnie założenie szkoły rękodzielniczej ${ }^{40}$. W Wiedniu już od roku działała wówczas powstała przy Muzeum Wyższa Szkoła Wzornictwa (Kunstgewerbeschule), mająca kształcić biegłych w sztuce i rzemiośle projektantów, którzy następnie znajdowaliby zatrudnienie w austriackich fabrykach, a także nauczycieli, którzy uczyliby w regionalnych szkołach technicznych zakładanych w Austro-Węgrzech ${ }^{41}$. W następnych latach podobne szkoły powstały przy regionalnych muzeach przemysłowych, m.in. w Pradze, Zagrzebiu czy Splicie ${ }^{42}$. W 1875 r. Lwowska Izba Handlowa wydała odezwę, by planowaną od trzech lat szkołę rysunku założyć właśnie przy Muzeum Przemysłowym, przywołując jego już wówczas bogate kolekcje biblioteczne, wzorów rysunkowych i modeli, a także załączając jako wzór regulamin wiedeńskiej Kunstgewerbeschule i jej plan nauczania ${ }^{43}$. W ten sposób, w 1876 r. przy Muzeum założona została C.K. Powszechna Szkoła Przemysłowa Rysunków i Modelowania, która w pierwszym okresie działalności Muzeum miała jednak charakter szkoły zawodowej, gdzie na krótkich kursach praktycznych, m.in. z hafciarstwa, snycerstwa czy rysunku artystycznego, kształcono różnego rodzaju rzemieślników, uzupełniając tym samym ofertę miejskiej

${ }^{39}$ Czterdziestolecie Izby Stowarzyszeń..., s. 8-12.

40 Tamże, s. 15.

${ }^{41}$ M. Rampley, dz. cyt., s. 251.

42 Tamże.

${ }^{43}$ MEiPA, Korespondencja Muzeum Przemysłowego, 1875 r., Odezwa Izby Handlowej, 23 IV $1875 \mathrm{r}$. 
szkoły przemysłowo-handlowej, która posiadała oddziały budownictwa, mechaniki, chemii i handlu ${ }^{44}$.

Szkoła przy Muzeum Techniczno-Przemysłowym powstała jeszcze wcześniej, a jej inicjatorem i pomysłodawca był Baraniecki, który zainspirowany przykładami paryskimi i londyńskimi, założył niezwykle popularne kursy wyższe adresowane do kobiet. W 1864 r. na fali ruchów emancypacyjnych w Paryżu została założona École supérieure des arts appliqués Duperré, pierwsza kobieca szkoła zawodowa, która miała kształcić w kierunkach rzemieślniczych i artystycznych. W tym samym czasie w Londynie kobiety mogły już uczęszczać na kursy organizowane przez Royal Academy of Arts, szkołę działająca przy South Kensington Museum czy założone w 1868 r. Slade Schools of Fine Arts przy uniwersytetach w Oksfordzie, Cambridge i University College w Londynie ${ }^{45}$. Krakowski wyższy zakład naukowy dla kobiet oferował naukę na trzech wydziałach (przyrodniczym, historyczno-literackim i sztuk pięknych), a ze względów logistycznych nie mógł prowadzić zajęć dotyczących zagadnień handlu i gospodarki. Szczególna uwaga poświęcona była zajęciom na wydziale sztuk pięknych, gdzie uczono rysunku, grafiki, malarstwa i zastosowania tych umiejętności dla ornamentyki i przemysłu ${ }^{46}$. Prace słuchaczek wystawiane były w muzeum, a także wysyłane na wystawy krajowe i światowe. Kursy, częściowo odpłatne, częściowo finansowane przez miasto, cieszyły się wielkim powodzeniem i gromadziły rokrocznie blisko 150 słuchaczek. Co ciekawe, założony równolegle Wyższy Zakład Naukowy dla Mężczyzn nie był równie popularny i funkcjonował tylko przez siedem lat (1870-1877) ${ }^{47}$.

O ile szkoły działające przy obu muzeach wzorowane były na przykładach wiedeńskich, londyńskich i paryskich, to założona przy Muzeum Przemysłowym we Lwowie Krajowa Ceramiczna Stacja Doświadczalna była wyjątkowa i wpisywała się w rozkwit szkół wspierających rozwój lokalnych rzemiosł (hafciarstwo, koszykarstwo, ceramika czy snycerstwo), jaki miał miejsce w Galicji w latach siedemdziesiątych i osiemdziesiątych ${ }^{48}$. Została założona, by wspierać wiedzą i doświadczeniem lokalną sieć szkół ceramiki, przede wszystkim tę w Kołomyi, prowadzić badania i eksperymenty dotyczące używanych materiałów czy

${ }_{44}$ T. Merunowicz, Opieka kraju nad szkolnictwem przemysłowym w Galicji, Lwów 1887, s. $6-7$.

${ }^{45}$ L. Lampela, Women's Art Education Institutions in $19^{\text {th }}$ Century England, „Art Education" 46, 1993, nr 1, s. 64-67.

${ }^{46}$ Z. Beiersdorf, dz. cyt., s. 135-137.

47 Tamże.

48 T. Merunowicz, dz. cyt. 
tradycyjnych wzorów, a na bazie bogatej kolekcji ceramiki i fajansów, która była jedną ze specjalności muzeów, kształcić rzemieślników.

Oba muzea, a zwłaszcza lwowskie, były ważnymi ośrodkami promującymi rozwój i badania nad lokalnymi rzemiosłami na galicyjskiej prowincji. Od początku współpracowały z C.K. Towarzystwem Gospodarczym, które od lat siedemdziesiatych organizowane przez siebie lokalne wystawy gospodarcze zaczęło wzbogacać o część poświęcona przemysłowi domowemu. W powołanej w 1877 r. przy Wydziale Krajowym Komisji do Spraw Rozwoju Przemysłu Domowego, która miała m.in. urządzać wystawy, prowadzić badania statystyczne, dbać o rozwój szkolnictwa przemysłowego i muzeów przemysłowych w Galicji, nieprzypadkowo znaleźli się członkowie Rady Nadzorczej Muzeum Przemysłowego i osoby z tą instytucją zwiazane (m.in. Włodzimierz Dzieduszycki, Ludwik Wierzbicki) ${ }^{49}$, a Komisja w swoje inicjatywy często angażowała krakowskie i lwowski muzea. Z myślą o prowincji pomyślane były również pracownie galwanoplastyczna i fotograficzna Muzeum Przemysłowego oraz pracownia odlewów gipsowych (odlewnia) Muzeum Techniczno-Przemysłowego. Na wzór muzeów londyńskiego i wiedeńskiego miały one dostarczać tanich reprodukcji, które mogłyby być używane w lokalnych szkołach i stowarzyszeniach.

Krakowskie i lwowskie muzea od początku swej działalności organizowały wykłady otwarte, których tematyka w pełni odzwierciedlała ich szerokie zainteresowania i wyznaczone cele - z jednej strony miały one charakter popularnonaukowy, z drugiej poruszały kwestie praktyczne związane z przemysłem, handlem i rękodziełem. Pierwszy cykl wykładów Muzeum Przemysłowego, zorganizowany od listopada 1875 do kwietnia 1876 r., przewidywał np. odczyty poświęcone takim zagadnieniom jak barwy, fotografia i jej zastosowanie w przemyśle, kamienie szlachetne, powietrze, zastosowanie gazometrów w drobnym przemyśle, muzea przemysłowe, kredyt rękodzielniczy, drzewo, galwanoplastyka, spółki rękodzielnicze i przemysłowe, wpływ architektury na przemysł, żelazo i stal. Wykłady prowadzone w obu instytucjach miały charakter popularny, organizowane były w niedziele, a adresowane przede wszystkim do rękodzielników i uczącej się młodzieży, dla których zagwarantowano bezpłatne wejściówki. Na ich pomieszczenie wygospodarowane zostały specjalne wnętrza w budynkach udostępnianych przez miasta. Obie instytucje miały jednak problem z ich zapełnieniem, a Muzeum Techniczno-Przemysłowe w 1876 r. zdecydowało się nawet na zawieszenie tej formy działalności. W Krakowie w tym okresie zaczęło bowiem

49 Tamże. 
funkcjonować wiele szkół i kursów wieczorowych, co zwiększało konkurencję i powodowało odpływ słuchaczy ${ }^{50}$.

W'śód najwcześniejszych wystaw czasowych Muzeum Techniczno-Przemysłowego należy wymienić lekarsko-przyrodnicza, zorganizowaną przy okazji pierwszego zjazdu polskich przyrodników i lekarzy, który odbył się w Krakowie w 1869 r. ${ }^{51}$ Tego typu, niekiedy wręcz efemeryczne wystawy, aranżowane przy okazji konferencji naukowych, literackich bądź artystycznych organizowanych w tym okresie w Krakowie i we Lwowie, doskonale odzwierciedlają charakter ówczesnego życia kulturalnego i naukowego, które toczyło się w atmosferze współpracy miedzy różnorodnymi instytucjami i organizacjami. W ostatniej ćwierci XIX w. wystawy były nieodłacznym elementem popularnych w tym okresie zjazdów naukowych, literackich, artystycznych czy profesjonalnych. W przypadku wielkich kongresów międzynarodowych organizowanych w takich ośrodkach jak Londyn, Paryż, Wiedeń czy Petersburg rozmachem przypominały one wystawy światowe. Wspomniany wyżej zbiór strojów włościańskich i wyrobów przemysłu domowego, zgromadzony dzięki licznym darom w Muzeum Techniczno-Przemysłowym, w 1883 r. wystawiony został po raz pierwszy przy okazji zjazdu artystów i literatów polskich ${ }^{52}$. Jak wynika ze sprawozdania z działalności Muzeum Techniczno-Przemysłowego, ekspozycja ta w ciagu kilkunastu kolejnych miesięcy była wielokrotnie prezentowana przy różnych okazjach, zapewne także podczas Zjazdu Historyczno-Literackiego im. Jana Kochanowskiego zorganizowanego w 1884 r. w Krakowie.

Najważniejszą ekspozycją tego typu była Wystawa archeologiczna polsko-ruska, zorganizowana we wnętrzach Politechniki Lwowskiej przy okazji pierwszego zjazdu polskich i ruskich archeologów w $1885 \mathrm{r} .{ }^{53} \mathrm{Ta}$ inicjatywa grupy kilkunastu krakowskich i lwowskich archeologów planowana była długo i starannie. Pomysł spotkania narodził się podczas wspólnej narady w Haliczu, gdzie prowadzone były wówczas wykopaliska pod kierunkiem profesora Uniwersytetu Lwowskiego, Isydora

${ }^{50}$ Z. Beiersdorf, dz. cyt., s. 137.

${ }^{51}$ A. Baraniecki, Krótkie sprawozdanie z dwunastoletniej działalności $i$ z obecnego stanu Muzeum techniczno-przemysłowego krakowskiego $i$ zakładów przy nim istniejacych, ustanowione $z$ powodu zapowiedzianej pierwszym programem bytności Najjaśniejszego Pana w tym zakładzie, Kraków [b.d.], s. 4.

${ }^{52}$ ANK, Muzeum Przemysłu Artystycznego w Krakowie, 4, Sprawozdania z działalności (1868-1900), Sprawozdanie z działalności Muzeum techniczno-przemysłowego miejskiego w Krakowie od chwili powstania instytucji a szczególnie w roku 1886, k. 40.

${ }_{53}$ T. Nieczuja-Ziemięcki, Polsko-ruska wystawa archeologiczna we Lwowie, Kraków 1885. 
Szaranewycza (1829-1901), a ambicje galicyjskich badaczy podsyciły dwa podobne zjazdy archeologiczne o charakterze regionalnym, które zorganizowano niezależnie od siebie w $1884 \mathrm{r}$. we Wrocławiu i Odessie ${ }^{54}$. Zaplanowany na lipiec 1885 r. trzydniowy zjazd miał poruszyć wszystkie najważniejsze zagadnienia dotyczące archeologii, sztuki i etnografii Rusi (zaplanowane były posiedzenia w sekcjach $\mathrm{z}$ referatami poświęconymi m.in. sztuce cerkiewnej na Rusi, zabytkom prehistorycznym na Podolu i Pokuciu, ornamentyce ludowej na Rusi, topografii i rozwojowi historycznemu miasta Lwowa ${ }^{55}$. Oprócz debat specjalistów przewidziane były również posiedzenia otwarte, przeznaczone dla szerokiej publiczności, zamierzone zaś z rozmachem wystawy przedmiotów artystycznych wytworzonych na Rusi lub powiąanych z tymi ziemiami oraz regionalnych strojów ludowych i wyrobów włościańskich miały być jej największą atrakcją. Ponadto zaplanowano wycieczki archeologiczne do najważniejszych stanowisk w regionie (Halicz, Bohorodczany, Bołdy Połanickie), które miały się odbyć po zakończeniu obrad ${ }^{56}$. Inicjatywa została zrealizowana $\mathrm{w}$ ten sam sposób co inne instytucjonalne, wystawiennicze czy edukacyjne przedsięwzięcia w tym okresie. W $1884 \mathrm{r}$. ukonstytuował się komitet dla zorganizowania zjazdu, w skład którego weszli badacze i zarazem wpływowi mieszkańcy Lwowa i Krakowa, m.in. Wojciech Dzieduszycki (1848-1909), poseł oraz członek Rady Państwa i zarazem konserwator urzędowy dla Galicji Wschodniej, dyrektor archiwum miejskiego i radca magistratu Karol Widman (1821-1891) czy wspomniany już Karol Lanckoroński. Komitet nie tylko uzyskał środki na zorganizowanie zjazdu od Wydziału Krajowego, ale do projektu wciagnął też inne krakowskie instytucje i osobistości. Zasiadało w nim kilku członków Rady Nadzorczej Muzeum Przemysłowego: Włodzimierz Dzieduszycki, Ludwik Wierzbicki i architekt Julian Zachariewicz (1837-1898), czyli osobistości zaangażowane w wiele innych lwowskich projektów i inicjatyw ${ }^{57}$. Sam zjazd i wystawa odbyły się w gmachu Instytutu Politechnicznego, który posiadał ku temu warunki, a oba wydarzenia należy rozpatrywać jako dzieło zbiorowe wielu instytucji i jednostek zaangażowanych $\mathrm{w}$ przygotowania. Szczególną rolę odegrał wspomniany już Wierzbicki, architekt i inżynier kolejnictwa, poseł na Sejm Krajowy, jeden ze współzałożycieli i najbardziej aktywnych

${ }^{54}$ MEiPA, Korespondencja Muzeum Przemysłowego, 1885 r., Odezwa Komitetu urządzajacego zjazd archeologiczny we Lwowie, listopad $1884 \mathrm{r}$.

55 Tamże.

56 Tamże.

${ }^{57}$ MEiPA, Korespondencja Muzeum Przemysłowego, 1885 r., Rękopiśmienna notatka, b.d. [1885 r.]. 
działaczy skupionych wokół Muzeum. Nie tylko nadzorował on koncepcję i montaż wystawy, ale był też głównym współautorem albumu opublikowanego po jej zakończeniu ${ }^{58}$. Ta trudna w wykonaniu i kosztowna edycja $\mathrm{w}$ formie teki z pięćdziesięcioma tablicami fototypicznymi wykonanymi w cenionym lwowskim zakładzie fotograficznym Edwarda Trzemeskiego, została wydana zgodnie z jedna z uchwał kończących zjazd, dzięki środkom ofiarowanym na ten cel przez Karola Lanckorońskiego, Wołodysława Fedorowycza (1845-1918), przewodniczacego Towarzystwa Proswita i mecenasa wielu przedsięwzięć majacych na celu badanie i promocję kultury rusińskiej, oraz Filipa Zaleskiego, c.k. namiestnika Galicji ${ }^{59}$. Jak wynika z korespondencji Wierzbickiego z profesorem historii sztuki Uniwersytetu Jagiellońskiego i dyrektorem Muzeum Książąt Czartoryskich Marianem Sokołowskim (1839-1911) ${ }^{60}$, Wierzbicki nadzorował druk albumu, którego układ i grafika były zreszta wzorowane na podobnej publikacji, wydanej przez Muzeum Przemysłowe we Lwowie: Wzory przemystu domowego włościan na Rusi ${ }^{61}$.

Oba muzea należały też do najważniejszych inicjatorów i współorganizatorów wystaw krajowych urządzanych we Lwowie i Krakowie oraz na prowincji.

Odrębnym rodzajem działalności ekspozycyjnej były wystawy poświęcone współczesnym krajowym wyrobom rzemieślniczym, w szczególności tym lokalnym. Specjalizowało się w nich zwłaszcza Muzeum Przemysłowe, gdzie określane były one mianem wystaw specjalnych dla przemysłowców i rękodzielników ${ }^{62}$. Organizowano je od $1881 \mathrm{r}$. w specjalne wynajętych do tego pomieszczeniach, a ich głównym celem było rozpropagowanie dobrej jakości wyrobów krajowych. Dla rzemieślników była to dobra i niedroga forma reklamy, stąd były one niezwykle popularne (na pierwszej np. udało się zgromadzić ponad 4 tys. eksponatów). Wystawy miały charakter tematyczny i poświęcone były wybranej gałęzi rzemieślniczej: pierwsza prezentowała wyroby tkackie przemysłu domowego, druga - wyroby z drzewa i koszykarskie. Przy ich organizacji Muzeum

${ }^{58}$ Wystawa archeologiczna polsko-ruska urzqdzona we Lwowie w roku 1885, Lwów 1886.

59 Tamże, s. 28.

${ }^{60}$ MEiPA, Korespondencja Muzeum Przemysłowego, 1885 r., Ludwik Wierzbicki do Mariana Sokołowskiego, 24 XI [II?] 1885 r.

${ }^{61}$ Wzory przemystu domowego wtościan na Rusi, red. L. Wierzbicki, Lwów 1880-1889 .

${ }^{62}$ Wystawa robót stolarskich, tokarskich, kołodziejskich, bednarskich $i$ koszykarskich $w$ Muzeum Przemystowym we Lwowie w r. 1882, Odezwa Zarządu Muzeum Przemysłowego, Lwów 1882. 
korzystało ze swojej sieci kontaktów z lokalnymi szkołami przemysłowymi, muzeami i towarzystwami społecznymi. Przy okazji wystawy wyrobów z drzewa i koszykarskiej odezwa do ewentualnych wystawców została zarówno umieszczona $\mathrm{w}$ prasie, jak i skierowana bezpośrednio do Krakowskiego Towarzystwa Technicznego (które powołało nawet specjalną komisję, mająca pośredniczyć między Muzeum a krakowskim rzemieślnikami) ${ }^{63}$ czy Szkoły Fachowej dla Artystycznego Przemysłu z Drzewa w Zakopanem ${ }^{64}$.

Tak różnorodna i wieloaspektowa działalność obu muzeów odzwierciedlona była w zgromadzonych w pierwszych dziesięcioleciach zbiorach. Na wzór muzeów londyńskiego i wiedeńskiego pierwsze zakupy Baranieckiego w Londynie i Paryżu oraz komitetu powołanego przez Lwowską Izbę Przemysłową na wystawie światowej w Wiedniu miały dostarczyć wzorców rzemiosła produkowanego w światowych ośrodkach dla galicyjskich wytwórców ${ }^{65}$. W następnych latach dzięki darom i zakupom obie kolekcje objęły również wszelkiego rodzaju przedmioty historycznego rzemiosła, współczesnych wytworów przemysłowych, zarówno krajowych, jak i zagranicznych. Zbierano także okazy geologiczne i przyrodnicze, zwłaszcza te odnoszace się do Galicji. Nacisk położony był również na najnowsze wynalazki techniczne, maszyny i prototypy, z którymi chciano zapoznać lokalnych producentów. Przedmioty te, wzorem muzeów zagranicznych, porządkowane były według materiału i tworzyły razem obraz materialnego świata. Nie był on bynajmniej ograniczony tylko do Galicji lub Europy. Na przykład Muzeum Techniczno-Przemysłowe w latach osiemdziesiatych przyjęło do swoich zbiorów kolekcję okazów z wyprawy do Zachodniej Afryki i Kamerunu, ofiarowane przez Stefana Szolc-Rogozińskiego (1861-1896), a także inne przedmioty z obszaru kultur pozaeuropejskich ${ }^{66}$.

Charakterystycznym rysem muzeów przemysłowych w Austro-Węgrzech, w szczególności tych prowincjonalnych, był nacisk, jakie kładły one z jednej strony na zbieranie i badanie tzw. przemysłu domowego, czyli lokalnych, ludowych rzemiosł i wytwórczości, z drugiej -

${ }^{63}$ MEiPA, Korespondencja Muzeum Przemysłowego, 1882 r., Krakowskie Towarzystwo Techniczne do Rady Nadzorczej Muzeum Przemysłowego, Kraków, 3 IV $1882 \mathrm{r}$.

${ }^{64}$ Tamże, Franciszek Nowzik do Rady Nadzorczej Muzeum Przemysłowego, Zakopane, 12 III $1882 \mathrm{r}$.

65 Z. Beiersdorf, dz. cyt., s. 129-134; MEiPA, Korespondencja Muzeum Przemysłowego, 1873/1874 r., liczne spisy i korespondencje dotyczące zakupów na Wystawie Światowej w Wiedniu.

${ }^{66}$ Z. Beiersdorf, dz. cyt., s. 145. 
historycznych lokalnych wyrobów rzemiosła i stylu. Oba rodzaje wytworów pojmowane były nieraz w kategoriach narodowych. W działalności kolekcjonerskiej i badawczej dotyczacej kultury ludowej i narodowej obie instytucje zasięgiem swoich kontaktów i poszukiwań obejmowały nie tylko Galicję, ale historyczne ziemie Polski. Oba np. korespondowały i dokonywały regularnych zakupów historycznego rzemiosła w Gdańsku za pośrednictwem Jana Roehra (1816-1877). Muzeum Przemysłowe współpracowało ponadto blisko z badaczami, kolekcjonerami i stowarzyszeniami rusińskimi we Lwowie i Galicji Wschodniej.

Jak świadczą o tym liczne wzmianki w sprawozdaniach i korespondencji, od początku działalności obie instytucje stały się częścią siatki austro-węgierskich muzeów wzornictwa i przemysłu, na których czele stało muzeum wiedeńskie. Raz albo dwa razy do roku w różnych ośrodkach Cesarstwa odbywały się spotkania przedstawicieli austro-węgierskich muzeów, organizowano wspólne przedsięwzięcia wystawiennicze, prowadzono wymianę czasopism i wydawnictw, reprodukcji. Oba muzea miały też ambicje europejskie, które z sukcesem zrealizowały w ważnych przedsięwzięciach wydawniczych, opartych na wysokiej klasy reprodukcji.

Wśród najwcześniejszych i najważniejszych przedsięwzięć Muzeum Przemysłowego, których inicjatorem i częściowo fundatorem był Baraniecki, wymienić należy projekt wykonania odlewów gipsowych z elementów dekoracyjnych czołowych krakowskich zabytków epoki renesansu, w szczególności kaplicy Zygmuntowskiej. W oczywisty sposób nawiazzywał on i zapewne był inspirowany zamierzonym na wielką skalę projektem systematycznego zbierania odlewów gipsowych sztuki i rzemiosła całego świata zachodniego, prowadzonym systematycznie od lat sześćdziesiątych w South Kensington Museum ${ }^{67}$. Krakowskie odlewy nie tylko znalazły się wśród najważniejszych eksponatów w Muzeum, oferowane były również na sprzedaż, zarówno polskim, jak i europejskim akademiom sztuk pięknych oraz muzeom rzemiosła i wzornictwa ${ }^{68}$. Stały się one również podstawą innego ważnego przedsięwzięcia - eleganckiego albumu fotograficznego wydanego po polsku i po francusku, a wykonanego przez jednego z profesjonalnych krakowskich fotografów, Awita

${ }^{67}$ Ewentualne kontakty Baranieckiego z inicjatorem projektu, Henrym Cole'em wymagają kwerend w archiwach South Kensington Museum. O londyńskiej kolekcji odlewów gipsowych por. m.in. D. Bilbey, M. Trusted, „The Question of Casts”. Collecting and Later Reassessment of the Cast Collections at South Kensington, w: Plaster Casts. Making, Collecting, and Displaying from Classical Antiquity to the Present, red. R. Frederiksen, E. Marchand, Berlin 2010, s. 465-483.

${ }^{68}$ Cennik odlewów gipsowych szkolnych $w$ odlewni Muzeum Techniczno-Przemystowego, Kraków 1881. 
Szuberta ${ }^{69}$. Ze względu na ówczesne możliwości techniczne fotografie te musiały zostać zrobione na podstawie odlewów gipsowych. Album reprodukcji wykonany w nowoczesnej technice fotografii przeznaczony był na półki bibliotek, muzeów, instytutów i towarzystw naukowych, a także kolekcjonerów i badaczy, miał na celu włączyć kulturę i sztukę miasta i narodu do uniwersalnego kanonu sztuki i wzornictwa, podobnie jak odlewy, które miały trafić do najważniejszych europejskich kolekcji tego typu, ilustrujących kanon najważniejszych zachodnich zabytków rzeźby, architektury i ornamentyki.

Tak jak wizytówka krakowskiego muzeum był album fotograficzny Awita Szuberta, tak Muzeum Przemysłowe zaprezentowało swój profil i specyfikę w albumie poświęconym kulturze włościańskiej na Rusi ${ }^{70}$. W kilku zeszytach prezentujących poszczególne rodzaje wyrobów (hafty, garncarstwo czy ciesielka) na chromolitograficznych tablicach ukazane zostały charakterystyczne okazy pochodzące zarówno z kolekcji Muzeum, jak i ze zbiorów prywatnych. Zeszyty albumu, wydane w czterech równoległych wersjach językowych (polskiej, ukraińskiej, francuskiej i niemieckiej), przeznaczone był zarówno na rynek krajowy, jak i zachodni: miały zaświadczać o wyjątkowości kultury regionu i narodu, a także o wysokim statusie samego Muzeum. Album powstał w całości na miejscu: rysunki przygotowawcze wykonane zostały m.in. przez uczestników kursów rysunkowych, a tablice odbite w zakładach litograficznych Towarzystwa Przemysłowego we Lwowie ${ }^{71}$.

Pod koniec XIX w. dotychczasowa formuła muzeów przemysłowych uległa znacznej ewolucji. Uporządkowane według materiału i techniki ekspozycje przedmiotów współczesnych i z przeszłości stopniowo odchodziły do lamusa, ustępując miejsca nieraz zachwycającym bogactwem i aranżacją ekspozycjom poświęconym historii rzemiosła artystycznego, ułożonym historycznie, często w aranżacjach składających się na tzw. period rooms - czyli sale w najdrobniejszym detalu odtwarzajace wygląd pomieszczeń charakterystycznych dla danej epoki i regionu. Muzea te straciły w tym okresie swój encyklopedyczny charakter,

69 A. Szubert, Album ozdób z kaplicy Zygmuntowskiej $i$ z dwóch nagrobków kanonika Stanistawa Borka (†1556) $i$ Wielkiego Marszatka Piotra Kmity (†1505) $w$ Katedrze Krakowskiej, Kraków 1878.

70 Wzory przemystu domowego włościan na Rusi...

${ }^{71}$ MEiPA, Korespondencja Muzeum Przemysłowego, 1885 r., Rada Nadzorcza Muzeum do Mariana Sokołowskiego, dyrektora Muzeum XX Czartoryskich, 24 II 1886 r. 
a także wielorakie funkcje społeczne, edukacyjne i naukowe. Było to niewątpliwie efektem postępującej specjalizacji naukowej, edukacyjnej, a także industrializacji. Również krakowskie i lwowskie muzea przeszły podobną ewolucję. Od lat dziewięćdziesiątych toczyły się dyskusje nad przeformułowaniem ich misji, a w obu ośrodkach zakładane były instytucje, które przejmowały niektóre z ich zadań i celów (np. Muzeum Technologiczne założone w 1898 r. przy Izbie Handlowo-Przemysłowej, Muzeum Towarzystwa Ludoznawczego utworzone w 1895 r. we Lwowie czy dział etnograficzny powstały przy Muzeum Narodowym w Krakowie w 1904 r.). W 1914 r. nastapiło ponadto przerwanie międzynarodowej sieci kontaktów, zwłaszcza tej opartej na muzeach przemysłowych w Austro-Węgrzech, co całkowicie zmieniło perspektywę badawcza, kolekcjonerską i edukacyjną obu, działających już w innych warunkach geopolitycznych, instytucji.

\section{Bibliografia}

Art and Design for All. The Victoria and Albert Museum, red. J. Bryant, London 2011.

Beiersdorf Z., Muzeum Techniczno-Przemystowe w Krakowie, „Rocznik Krakowski" 57, 1991, s. 129-164.

Bilbey D., Trusted M., „,The Question of Casts”. Collecting and Later Reassessment of the Cast Collections at South Kensington, w: Plaster Casts. Making, Collecting, and Displaying from Classical Antiquity to the Present, red. R. Frederiksen, E. Marchand, Berlin 2010, s. 465-483.

Busch J.T., Futter C.L., Lee Błaszczyk R., Inventing the Modern World. Decorative Arts and the World's Fairs, 1851-1939, New York 2012.

Cultures of International Exhibitions 1840-1940. Great Exhibitions in the Margins, red. M. Filipová, Farnham 2015.

Curran K., The Invention of the American Art Museum. From Craft to Kulturgeschichte 1870-1930, Los Angeles 2016.

Czterdziestolecie Izby Stowarzyszeń rękodzielniczych we Lwowie, oprac. J. Starkel, Lwów 1916.

Greenhalgh P., Ephemeral Vistas. The Expositions Universelles, Great Exhibitions and World's Fairs, 1851-1939, Manchester 1988.

Hapanowicz P., Adrian Baraniecki - prekursor polskiego muzealnictwa przemystowego, „Muzealnictwo” 57, 2016, s. 16-25.

Hapanowicz P., Działalność Muzeum Techniczno-Przemystowego w Krakowie $i$ jego likwidacja w latach 1949-1950, „Zarządzanie w Kulturze” 8, 2007, s. $43-62$.

Kasprzak A.J., Skoropadowa H., Europejskie szkto od XVI do poczatku XIX wieku w zbiorach Muzeum Etnografii i Przemystu Artystycznego Instytutu 
Narodoznawstwa Narodowej Akademii Ukrainy we Lwowie, Warszawa 2008.

Lampela L., Women's Art Education Institutions in $19^{\text {th }}$ Century England, „Art Education" 46, 1993, nr 1, s. 64-67.

Merunowicz T., Opieka kraju nad szkolnictwem przemysłowym $w$ Galicji, Lwów 1887.

Nieczuja-Ziemięcki T., Polsko-ruska wystawa archeologiczna we Lwowie, Kraków 1885.

Rampley M., Design Reform in the Habsburg Empire: Technology, Aesthetics and Ideology, „Journal of Design History” 23, 2010, nr 3, s. 247-264.

Rampley M., Prokopovych M., Veszprémi N., Liberalism, Nationalism and Design Reform in the Habsburg Empire. Museums of Design, Industry and Applied Arts, New York 2020.

Szablowska A.A., Seńkìw M., Plakat polski ze zbiorów Muzeum Etnografii $i$ Przemystu Artystycznego Instytutu Narodoznawstwa Narodowej Akademii Ukrainy we Lwowie, Warszawa 2009.

Szczerski A., Wzorce tożsamości. Recepcja sztuki brytyjskiej w Europie Środkowej około roku 1900, Kraków 2002.

Szubert A., Album ozdób z kaplicy Zygmuntowskiej $i$ z dwóch nagrobków kanonika Stanisława Borka (†1556) i Wielkiego Marszałka Piotra Kmity (†1505) w Katedrze Krakowskiej, Kraków 1878.

Więcek M., Dolińska M., Tomkowicz D., Zapomniane muzeum: Adrian Baraniecki i jego Muzeum Techniczno-Przemysłowe 1868-1950, Kraków 2013.

Wzory przemystu domowego włościan na Rusi, red. L. Wierzbicki, Lwów 1880-1889 .

Ewa Manikowska

Industrial museums in Kraków and Lviv. Origins and first stage of operation, 1868-1914

(Summary)

The article discusses the early stages in the activity of industrial museums founded in Kraków and Lviv. The analysis focuses on the period preceding the year 1914, during which both institutions formed part of the network of Austro-Hungarian industrial museums. The first part of the paper analyses this new museum concept, the prototype of which was the South Kensington Museum, with most institutions of that kind in Central Europe being modelled after the Imperial-Royal Museum of Art and Industry in Vienna. Particular emphasis is put on the importance of universal exhibitions in the development of this new type of urban institution. The second part presents the case studies of industrial museums in Kraków and Lviv as important centers of urban cultural and social life. The article analyses the statutes of both institutions and their collective administrative system comprising the municipal 
authorities, artisan guilds, chambers of commerce, and civic societies. It also describes the diverse group of donors indispensable for both museums' operation. The third part of the paper discusses the wide range of initiatives undertaken by the museums (many of them reaching far beyond the scope of what today is considered standard for museums): technical and industrial schools founded in Lviv, Kraków, and in smaller towns; research and promotion of cottage industry (Hausindustrie); wide-ranging educational activities; numerous exhibitions; the building of collections; publishing activities; cooperation with other institutions in Galicia and the Empire. The conclusions put emphasis on the importance of the year 1900 as a turning point in the museums' history, as it marked the beginning of discussions on reformulating the mission of both institutions.

Ewa Manikowska - pracuje w Instytucie Sztuki PAN. Specjalizuje się w dziejach kolekcjonerstwa, muzealnictwa, historii fotografii, zajmuje się również zagadnieniami dziedzictwa kulturowego. Autorka monografii Photography and Cultural Heritage in the Age of Nationalisms. Europe's Eastern Borderlands (1867-1945), Bloomsbury 2019.

Ewa Manikowska - employee of the Institute of Art, Polish Academy of Sciences. She specializes in the history of collecting, museum studies, history of photography. She also deals with issues connected to cultural heritage. She is the author of the monograph Photography and Cultural Heritage in the Age of Nationalisms. Europe's Eastern Borderlands (1867-1945), Bloomsbury, 2019.

E-mail: emanikowska@hotmail.com. 